\title{
PENGEMBANGAN PERANGKAT PEMBELAJARAN SD DENGAN MODEL PROBLEM BASED LEARNING (PBL) BERVISI SCIENCE, ENVIRONMENT, TECHNOLOGY AND SOCIETY (SETS) BERBANTUAN MIRACAST
}

\author{
Putri Yanuarita Sutikno \\ Novi Setyasto \\ Universitas Negeri Semarang \\ novisetyasto@mail.unnes.ac.id
}

\begin{abstract}
Abstrak
Jenis Penelitian ini adalah research and development (R\&D) yang bertujuan menghasilkan perangkat pembelajaran dengan model PBL bervisi Science, Environment, Technology, and Society (SETS) berbantuan Miracast yang valid, efektif, dan praktis (applicable) serta sesuai standar proses. Subjek uji coba adalah 42 peserta didik kelas IV SDN Sadeng 02, dan 03. Teknik pengumpulan data menggunakan tes, pengamatan, angket, wawancara, dan dokumentasi. Teknik analisis data menggunakan analisis deskriptif kualitatif dan kuantitatif. Hasil validasi tiga orang ahli terhadap perangkat pembelajaran telah memenuhi kriteria valid. Perangkat pembelajaran efektif untuk meningkatkan hasil belajar siswa yang ditunjukkan dengan hasil uji N-gain didapat nilai gain $\langle g\rangle$ sebesar 0,48 dalam kategori sedang dan peningkatan rata-rata nilai hasil belajar dari pretest 56 menjadi 77 pada saat posttest. Hasil pengamatan aktivitas peserta didik menunjukkan rata-rata skor 33 berada pada ketegori sangat tinggi. Kepraktisan perangkat pembelajaran terlihat dari respons sangat positif yang diberikan guru dan peserta didik terhadap perangkat pembelajaran. Berdasarkan hasil tersebut, diketahui perangkat pembelajaran sudah memenuhi kriteria valid, efektif, dan praktis.
\end{abstract}

Kata Kunci: perangkat pembelajaran, PBL, SETS, Miracast, hasil belajar.

\begin{abstract}
This was research and development based on 4-D model of Thiagarajan. This study aimed to develop valid, effective, and applicable learning tools using PBL model and SETS vision assisted by Miracast which were appropriate with Process Standard. The samples were 42 students of $4^{\text {th }}$ grade Sadeng 02, and 03 elementary schools. Data were derived from test, observation, questionnaire, interview, and documentation. Data were analysed using qualitative and quantitative descriptives. The learning tools have been qualified as valid based on three experts' judgements. Learning tools were effective to enhance students' learning outcomes which proved by gain $\langle g\rangle$ was 0.48 inclueded in medium category and the improvement of pretest and posttest average scores from 56 to 77. Students' activities observation showed an average score of 33 in very high category. Learning tools were also applicable which proved by teachers' and students' very positive responses toward the learning tools implementation. In conclusion, the learning tools have qualified valid, effective, and practicable criteria.
\end{abstract}

Keywords: learning tools, PBL, SETS, Miracast, learning outcomes.

\section{PENDAHULUAN}

Kurikulum 2013 telah mulai diimplementasikan di dunia pendidikan Indonesia dengan dikeluarkannya Permendikbud nomor 81a tahun 2013 tentang implementasi kurikulum. Kurikulum 2013 bertujuan untuk mempersiapkan manusia Indonesia agar memiliki kemampuan hidup sebagai pribadi dan warga negara yang beriman, produktif, kreatif, inovatif, dan afektif serta mampu berkontribusi pada kehidupan bermasyarakat, berbangsa, bernegara, dan peradaban dunia. Berdasarkan Permendikbud No. 24 tahun 2016 tentang kompetensi inti dan kompetensi dasar pelajaran pada kurikulum 2013, pelaksanaan pembelajaran di SD dilakukan dengan pendekatan pembelajaran tematikterpadu.

Untuk mencapai tujuan kurikulum 2013 maka dikeluarkanlah Permendikbud No. 22 tahun 2016 tentang Standar Proses, yang di dalamnya dinyatakan bahwa proses pembelajaran pada satuan pendidikan diselenggarakan secara interaktif, inspiratif, menyenangkan, menantang, memotivasi peserta didik untuk berpartisipasi aktif, serta memberikan ruang yang cukup bagi prakarsa, kreativitas, dan kemandirian sesuai 
dengan bakat, minat, dan perkembangan fisik serta psikologis peserta didik. Implikasi dengan dikeluarkannya standar proses adalah terjadinya pergeseran paradigma pengajaran ke paradigma pembelajaran, penggunaan pendekatan ilmiah (scientific), tematik terpadu (tematik antarmata pelajaran) sehingga perlu diterapkan pembelajaran berbasis penyingkapan/penelitian (discovery/inquiry learning). Untuk mendorong kemampuan peserta didik untuk menghasilkan karya kontekstual, baik individual maupun kelompok maka sangat disarankan menggunakan pendekatan pembelajaran yang menghasilkan karya berbasis pemecahan masalah (problem based learning/ project based learning). Guru juga dituntut untuk memiliki literasi teknologi yang mumpuni yaitu mampu memanfaatkan teknologi informasi dan komunikasi untuk meningkatkan efisiensi dan efektivitas pembelajaran.

Dikeluarkannya standar proses tersebut juga dikarenakan bahwa selama ini pembelajaran yang berpusat pada peserta didik (student center) masih belum dapat diwujudkan secara optimal terutama di tingkat sekolah dasar. Penyelenggaraan pembelajaran masih jauh dari apa yang menjadi tujuan pendidikan nasional. Proses pembelajaran lebih menekankan pada aspek kognitif, sehingga kemampuan mental yang dipelajari sebagian berpusat pada pemahaman bahan pengetahuan dan ingatan (Mulyasa, 2011). Achmad Sanusi dalam Winataputra (2008), mejelaskan bahwa pengajaran di sekolah cenderung menitikberatkan pada penguasaan hafalan, proses pembelajaran yang masih terpusat pada guru (teacher center), dan kurangnya pemanfaatan sumber belajar yang ada, sehingga situasi pembelajaran membosankan peserta didik. Wade (2002), dalam penelitiannya mengungkapkan $75 \%$ sampai $90 \%$ waktu pembelajaran di SD beracuan pada buku pelajaran sehingga peserta didik menjadi pasif dan membuat konsep-konsep tampak asing bagi peserta didik. Hal ini diperkuat dengan berita yang melaporkan bahwa guru di sejumlah daerah masih mengeluh kesulitan mengimplementasikan Kurikulum 2013 (Jawapos, 2016). Hasil evaluasi dinas Pendidikan juga menunjukkan bahwa guru kurang variatif dalam menerapkan model pembelajaran karena kurang paham langkah-langkah penerapannya (Darmawan, 2017).

Studi pendahuluan yang dilakukan di beberapa SD Gugus Drupadi Gunungpati Semarang yang di dalamnya meliputi SDN Sadeng 1-3, SDN Sukorejo 1-3, dan SDN Kandri 2, menunjukkan bahwa guru masih mengalami kesulitan dalam mengimplementasikan pembelajaran berbasis pemecahan masalah dan masih kesulitan dalam mengaplikasikan teknologi dalam pembelajaran di kelas sesuai dengan standar proses. Hal ini ditunjukkan dari hasil observasi awal dimana perangkat pembelajaran yang digunakan guru-guru di SD masih belum sesuai dengan standar proses, yaitu silabus dan RPP yang digunakan masih sederhana belum berpusat pada peserta didik, keterpaduan antar KI, KD, indikator, dan tujuan belum terpaparkan secara jelas, penerapan pendekatan scientific belum terlalu jelas, belum menggunakan pembelajaran berbasis pemecahan masalah. Hasil observasi pada saat pembelajaran menunjukkan guru masih mendominasi pembelajaran (teacher centered), penggunaan model pembelajaran masih kurang tepat belum sesuai dengan keadaan peserta didik, yaitu guru masih menyampaikan informasi dengan metode ceramah berpanduan pada Buku Siswa saja, serta belum maksimalnya penggunaan media menyebabkan peserta didik kurang aktif dan cepat merasa bosan, guru hanya menggunakan media gambar seadanya padahal SD-SD di Gugus Drupadi tersebut sudah memiliki perangkat pendukung seperti laptop, LCD, layar, dan sound system tetapi jarang digunakan dalam pembelajaran. Partisipasi peserta didik pun rendah yaitu cenderung pasif dan kurang konsentrasi karena peserta didik hanya mendengarkan penjelasan guru dan dibantu dengan media gambar seadaanya, kemudian mengerjakan soal yang diberikan. Berbagai macam hal tersebut mendorong perlu adanya pengembangan perangkat pembelajaran yang berpusat pada peserta didik, menggunakan pendekatan tematik terpadu, bermuatan karakter, berbasis pada pemecahan masalah, kontekstual, dan mampu meningkatkan aktivitas peserta didik dalam pembelajaran yang sesuai dengan kurikulum 2013 dan standar proses, serta operasional sehingga hasil belajar meningkat. Terkait dengan permasalahan tersebut, salah satu solusi yang dapat diterapkan adalah melalui pengembangan perangkat pembelajaran model problem based learning (PBL) bervisi Science, Environment, Technology, and Society (SETS) berbantuan MIRACAST.

PBL merupakan sebauh model pembelajaran dimana siswa belajar melalui pemecahan masalah (Barrows, 1996). Di dalam PBL, siswa belajar berpusat pada masah kompleks yang tidak hanya memiliki jawaban tunggal. Siswa bekerja dalam kelompok, mengidentifikasi dan mempelajari apa yang mereka butuhkan untuk memecahkan sebuah masalah. Mereka terlibat pada pembelajaran mandiri (self-directed learning) dan kemudian mengaplikasikan apa yang mereka pelajari untuk memecahkan masalah yang diberikan dan merefleksikan apa yang sudah mereka pelajari (Hmelo-Silver, 2004). Guru kelas dalam PBL tidak lagi berperan sebagai penyampai infomasi utama, tetapi sebagai seorang fasilitator dalam kegiatan diskusi antar siswa, mengarahkan siswa untuk belajar mandiri, dan mengarahkan siswa untuk mencapai pemahaman yang bermakna (Mergendoller, Maxwell, \& Bellisimo, 2006, Fullan, 2013). Flynn \& Klein (2001) dalam penelitiannya, menyimpulkan bahwa model PBL 
menciptakan pembelajaran yang lebih relevan dan bermakna bagi siswa melalui partisipasi aktif, menganalisis, dan berdiskusi serta memecahkan masalah nyata dengan pembelajaran lebih fokus pada penerapan konsep, teori, dan teknik pada masalah-masalah kehidupan nyata daripada sekedar menghafal fakta-fakta. Langkah-langkah pembelajaran dengan model PBL meliputi: 1) Orientasi peserta didik pada masalah; 2) Mengorganisasikan peserta didik untuk belajar; 3) Membimbing penyelidikan individual ataupun kelompok; 4) Mengembangkan dan menyajikan hasil karya; dan 5) Menganalisis dan mengevaluasi proses pemecahan masalah (Arends, 2012)

Selanjutnya, untuk membuat pembelajaran lebih bermakna dan kontekstual serta sesuai dengan pendekatan tematik terpadu, maka pembelajaran perlu bervisi SETS. Pembelajaran dengan visi SETS menekankan keterkaitan antar unsur SETS (Science, Environment, Technology, and Society) sebagai satu kesatuan tak terpisah dalam pembelajaran (Binadja, 1996). Visi SETS memberi warna pada cara pandang seseorang dalam melihat dan memahami sesuatu, dimana segala sesuatu itu dipahami memiliki keterkaitan unsur SETS, yang berpengaruh timbal balik secara keseluruhan, yang bisa tampak jelas dibandingkan dengan bila benda yang sama itu tidak diobservasi dengan visi SETS" (Binadja, 1999). Pembelajaran dengan visi SETS dapat mendukung terciptanya pembelajaran yang holistik sesusai dengan karakteristik siswa SD yang masih berada pada tahapan operasional konkrit (Piaget, 2001), siswa belajar melalui sesuatu yang nyata atau mereka alami.

Dalam usaha meningkatkan literasi teknologi guru-guru SD, maka perangkat pembelajaran dikembangkan dengan berbantuan salah satu teknologi modern "Miracast" yang dapat meningkatkan efektivitas dan efesiensi pembelajaran. Miracast merupakan sebuah perangkat standar peer-to-peer screencasting nirkabel terbentuk melalui koneksi Wi-Fi langsung dengan cara yang mirip dengan Bluetooth. Perangkat ini memungkinkan penayangan nirkabel gambar, audio, video dari desktop, tablet, ataupun smartphone ke projector (LCD), TV, dan monitor (Alliance, 2012). Dengan menggunakan Miracast, guru tidak perlu lagi dipermasalahkan dan terbuang waktunya untuk mencari dan menghubungkan kabel antar perangkat melainkan hanya perlu mengkoneksikan Wi-Fi. Miracast memungkinkan guru untuk menampilkan/ memproyeksikan file-file, foto, youtube, video streaming, live camera, websurfing, internet video, dll dari smartphone tanpa memerlukan kabel penghubung (Asus, 2013).

Pengembangan perangkat pembelajaran model problem based learning (PBL) bervisi Science, Environment, Technology, and Society (SETS) berbantuan MIRACAST diharapkan dapat mewujudkan pembelajaran yang sesuai dengan standar proses yaitu berpusat pada siswa, menanamkan karakter, menerapkan teknologi dimana siswa aktif belajar mandiri melalui proses pemecahan masalah kemudian mengkaitkan masalah dan solusi yang siswa temukan ke dalam unsur ilmu pengetahuan (Science), lingkungan (Environment), teknologi (Technology), dan masyarakat (Society) sehingga siswa mendapat pemahaman yang lebih luas dan bermakna akan suatu masalah. Siswa tidak hanya mendapat solusi akan sesuatu masalah tertentu tetapi mereka juga bisa memandang hubungan timbal balik akan solusi yang mereka temukan dengan ilmu pengetahuan yang ada, lingkungan, teknologi yang digunakan, dan pengaruhnya terhadap masayarakat. Penerapan pembelajaran Tematik terpadu-pun dapat terlaksana dengan baik. Tujuan penelitian ini adalah menghasilkan perangkat pembelajaran SD dengan model PBL bervisi Science, Environment, Technology, and Society (SETS) berbantuan MIRACAST yang valid, efektif, dan praktis (applicable) serta sesuai standar proses untuk digunakan dalam pembelajaran di SD sehingga aktivitas dan hasil belajar peserta didik meningkat.

\section{METODE}

Penelitian ini merupakan penelitian pengembangan yang mengacu pada model 4-D (Four D model) dari (Thiagarajan, Semmel, \& Semmel, 1974), tetapi dibatasi hanya sampai tahap develop. Subjek uji coba adalah peserta didik kelas IV SDN Sadeng 02 dan SDN Sadeng 03 Gugus Drupadi, Kecamatan Gunungpati, Kota Semarang. Penelitian ini melibatkan 42 peserta didik dan 4 orang guru SD. Teknik pengumpulan data menggunakan tes, pengamatan, angket, wawancara, dan dokumentasi. Teknik analisis data menggunakan analisis deskriptif kualitatif dan kuantitatif. Desain uji coba perangkat menggunakan desain eksperimen One Group PretestPostest Design (Sugiyono, 2013).

\section{HASIL DAN PEMBAHASAN}

\section{A. Karakteristik Perangkat Pembelajaran}

Karakteristik perangkat pembelajaran perangkat pembelajaran dengan model PBL bervisi SETS berbantuan Miracast diperoleh berdasarkan analisis kebutuhan dan perancangan pada tahap design. Hasil analisis tahap define atau tinjauan kebutuhan pengembangan perangkat pembelajaran di SD, menunjukkan sangat dibutuhkan pengembangan perangkat pembelajaran yang sesuai dengan standar proses, menerapkan model pembelajaran berbasis masalah, menerapkan teknologi modern, menerapkan pendekatan scientific, dapat meningkatkan aktivitas peserta didik, dan dapat meningkatkan hasil belajar peserta didik. Solusi yang ditetapkan berdasarkan analisis kebutuhan adalah melalui pengembangan perangkat pembelajaran dengan model problem based learning (PBL) bervisi SETS berbantuan Miracast yang dikembangkan sesuai standar proses. Perangkat pembelajaran dikembangkan untuk kelas IV SD dengan tema "Selalu Berhemat Energi", subtema "Energi Alternatif". perangkat pembelajaran yang dikembangkan meliputi: silabus, rencana pelaksanaan pembelajaran (RPP), lembar kerja peserta didik (LKPD), media, dan perangkat penilaian hasi belajar (PPHB) 


\section{B. Kevalidan Perangkat Pembelajaran}

Kevalidan perangkat pembelajaran model problem based learning (PBL) bervisi SETS berbantuan Miracast ditentukan berdasarkan penilaian dan pendapat 3 orang ahli (judgement expert). Perangkat pembelajaran dikatakan valid jika skor akhir rata-rata 3 validator memenuhi kriteria ketercapaian skor minimal perangkat kategori valid. Hasil rekapitulasi kevalidan perangkat pembelajaran dapat dilihat pada Tabel 1.

Tabel 1. Rekapitulasi Kevalidan Perangkat Pembelajaran

\begin{tabular}{|c|c|c|c|c|}
\hline No & Perangkat & $\begin{array}{c}\text { Kriteria } \\
\text { Ketercapaian }\end{array}$ & $\begin{array}{c}\text { Skor } \\
\text { Akhir } \\
\text { (Sa) } \\
\text { Hasil } \\
\text { Validasi }\end{array}$ & Keterangan \\
\hline 1. & Silabus & $\mathrm{Sa} \geq 31$ & 44,3 & Sangat valid \\
\hline 2. & RPP & $\mathrm{Sa} \geq 41$ & 58 & Sangat valid \\
\hline 3. & LKPD & $\mathrm{Sa} \geq 13$ & 18,3 & Sangat valid \\
\hline 4. & Media & $\mathrm{Sa} \geq 21$ & 29 & Sangat valid \\
\hline 5. & PPHB & & & \\
\hline & $\begin{array}{l}\text { a. Tes hasil } \\
\text { belajar } \\
\text { kognitif }\end{array}$ & $\mathrm{Sa} \geq 11$ & 14,6 & Sangat valid \\
\hline & b. LPAPD & $\mathrm{Sa} \geq 15$ & 21,6 & Sangat valid \\
\hline
\end{tabular}

Hasil validasi silabus menunjukkan bahwa skor akhir (Sa) rata-rata dari tiga validator adalah 44,3 dengan kategori sangat valid yang berarti telah memenuhi kriteria ketercapaian kevalidan silabus yaitu $\mathrm{Sa} \geq 31$. Perolehan skor akhir $(\mathrm{Sa})$ rata-rata validasi rencana pelaksanaan pembelajaran (RPP) adalah 58 yang termasuk dalam kategori sangat valid sehingga RPP sudah memenuhi kriteria ketercapaian kevalidan RPP yaitu $\mathrm{Sa} \geq 41$. Perangkat lembar kerja peserta didik (LKPD) setelah divalidasi oleh tiga orang ahli diperoleh skor akhir (Sa) 18,3 dengan kategori sangat valid sehingga LKPD sudah memenuhi kriteria ketercapaian kevalidan LKPD yaitu $\mathrm{Sa}$ $\geq 13$. Hasil validasi terhadap media menunjukkan skor akhir (Sa) 29 dengan kategori sangat valid sehingga media sudah memenuhi kriteria ketercapaian kevalidan perangkat yaitu $\mathrm{Sa} \geq 21$. Penilaian tiga validator terhadap perangkat tes hasil belajar kognitif menghasilkan skor akhir 14,6 dengan kategori sangat valid sehingga tes hasil belajar konitif sudah memenuhi kriteria ketercapaian yaitu $\mathrm{Sa} \geq 11$. Lembar pengamatan aktivitas peserta didik (LPAPD) dinilai oleh tiga validator ahli dan didapat skor akhir (Sa) 21,6 dengan kategori sangat valid karena sehingga LPAPD sudah memenuhi kriteria ketercapaian kevalidan LPAPD yaitu $\mathrm{Sa} \geq 15$. Berdasarkan hasil validasi oleh tiga orang ahli terhadap perangkat pembelajaran model problem based learning (PBL) bervisi SETS berbantuan Miracast sudah memenuhi kriteria valid.

\section{Keefektifan Perangkat Pembelajaran}

Keefektifan perangkat pembelajaran dalam penelitian ini dilihat dari ketercapaian hasil postes yang lebih baik dari hasil pretes, dan hasil pengamatan aktivitas peserta didik dalam pembelajaran di kelas real teaching dengan menerapkan perangkat pembelajaran dengan model problem based learning (PBL) bervisi SETS berbantuan Miracast.

\section{1) Hasil belajar Kognitif}

Ketuntasan hasil belajar kognitif dihitung dari jumlah peserta didik yang memperoleh nilai postes lebih besar dari KKM, yaitu 70 atau dengan kategori tuntas. Kelas dikatakan efektif apabila terdapat $\geq 75 \%$ peserta didik yang memperoleh nilai di atas KKM atau terdapat paling sedikit 23 peserta didik yang memperoleh nilai $\geq$ 70. Hasil belajar kognitif peserta didik diperoleh dari hasil pretes dan postes dalam bentuk soal pilihan ganda berjumlah 30 butir dengan empat pilihan jawaban. Pretes diberikan kepada peserta didik sebelum mendapatkan pembelajaran dengan model problem based learning (PBL) bervisi SETS berbantuan Miracast, dengan tujuan mendapatkan gambaran kemampuan awal peserta didik. Postes diberikan kepada peserta didik setelah mendapatkan pembelajaran melalui model problem based learning (PBL) bervisi SETS berbantuan Miracast, dengan tujuan untuk dibandingkan dengan hasil pretes sehingga diperoleh gambaran ada atau tidaknya peningkatan hasil belajar peserta didik. Hasil belajar kognitif peserta didik dikatakan meningkat jika hasil postes lebih baik dari pada hasil pretes. Rekapitulasi hasil pretes dan postes 30 peserta didik pada kelas uji coba real teaching dapat dilihat pada Tabel 2 .

Tabel 2. Rekapitulasi Hasil Pretes dan Postes Kelas Uji Coba Real Teaching

\begin{tabular}{llll}
\hline \multirow{2}{*}{ No } & Variabel & $\begin{array}{l}\text { Skor } \\
\text { Pretes }\end{array}$ & Postes \\
\hline 1 & Nilai terendah & 27 & 53 \\
2 & Nilai tertinggi & 73 & 100 \\
3 & Rata-rata & 56 & 77 \\
4 & $\begin{array}{l}\text { Jumlah peserta didik yang tuntas } \\
\text { (KKM = 65) }\end{array}$ & 8 & 25 \\
5 & $\begin{array}{l}\text { Jumlah peserta didik yang tidak } \\
\text { tuntas (nilai < 65) }\end{array}$ & 22 & 5 \\
6. & Persentase ketuntasan (\%) & 27 & 83 \\
\hline
\end{tabular}

terendah hasil postes adalah 53. Nilai tertinggi hasil pretes adalah 73 sedangkan nilai tertinggi hasil postes adalah 100. Rata-rata nilai pretes adalah 56 sedangkan rata-rata nilai postes adalah 77 . Jumlah peserta didik yang tuntas KKM pada saat pretes hanya 8 orang, sedangkan 22 orang lainnya tidak tuntas, sementara hasil postes menunjukkan 25 peserta didik telah tuntas KKM dan hanya 5 peserta didik yang masih belum tuntas. Prosentase ketuntasan klasikal pada saat pretes adalah $27 \%$ sedangkan prosentase ketuntasan klasikal pada saat postes adalah $83 \%$. Hasil perhitungan $\mathrm{N}$-gain juga menunjukkan adanya peningkatan hasil belajar 30 peserta didik di kelas uji coba real teaching yaitu sebesar 0,48 yang termasuk ke dalam kategori sedang karena terletak dalam rentang $0,30-0,70$ sehingga dapat diketahui penerapan perangkat pembelajaran model problem based learning (PBL) bervisi SETS berbantuan Miracast efektif untuk meningkatkan hasil belajar kognitif peserta didik. Hasil ini sesuai dengan hasil penelitian Flynn dan Klein (2001) dalam penelitiannya, menyimpulkan bahwa model PBL menciptakan pembelajaran yang lebih relevan dan bermakna bagi siswa melalui partisipasi aktif, menganalisis, dan berdiskusi serta memecahkan masalah nyata dengan pembelajaran lebih fokus pada penerapan konsep, teori, dan teknik pada masalah-masalah 
kehidupan nyata daripada sekedar menghafal fakta-fakta. Hasil tersebut juga sejalan dengan hasil penelitian yang dilakukan Rusilowati dkk (2012); Masfuah (2012), Wijayama (2018) yang menunjukkan bahwa penerapan visi SETS dalam pembelajaran dapat meningkatkan pemahaman dan ketuntasan belajar peserta didik. Pembelajaran dengan visi SETS dapat mendukung terciptanya pembelajaran yang holistik sesusai dengan karakteristik siswa SD yang masih berada pada tahapan operasional konkrit (Piaget, 2001), siswa belajar melalui sesuatu yang nyata atau mereka alami.

\section{2) Aktivitas Peserta Didik}

Hasil pengamatan aktivitas pada peserta didik selama 2 kali pertemuan dalam pembelajaran di kelas real teaching dengan model problem based learning (PBL) bervisi SETS berbantuan Miracast menunjukkan jumlah peserta didik yang mendapatkan skor aktivitas dengan kategori sangat tinggi dan tinggi pada pertemuan pertama dan kedua sudah memenuhi kriteria keberhasilan penelitian untuk aktivitas peserta didik yaitu skor akhir (Sa) minimal 23 dari 30 peserta didik menunjukkan kategori $\geq$ tinggi. Hasil rekapitulasi aktivitas peserta didik dari pertemuan ke-1 dan ke-2 menunjukkan adanya perubahan jumlah peserta didik dengan kategori aktivitas sangat tinggi, tinggi, dan rendah. Perubahan tersebut dapat divisualisasikan pada Gambar 1 sebagai berikut.

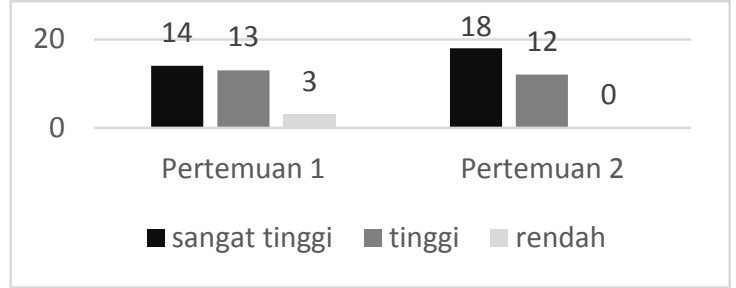

Gambar 1. Peningkatan Aktivitas Peserta Didik

Hasil pengamatan pada pertemuan 1 didapat 14 peserta didik mendapatkan skor aktivitas dengan kategori sangat tinggi, 13 peserta didik mendapatkan skor aktivitas dengan kategori tinggi sedangkan 3 peserta didik sisanya mendapatkan skor aktivitas dengan kategori rendah. Hasil pengamatan aktivitas peserta didik pada pertemuan ke-2 menunjukkan 18 peserta didik mendapatkan skor aktivitas dengan kategori sangat tinggi, 13 peserta didik lainnya mendapat skor aktivitas dengan kategori tinggi sehingga tidak ada peserta didik yang mendapat skor aktivitas dengan kategori rendah. Rekapitulasi hasil pengamatan aktivitas peserta didik juga menunjukkan adanya peningkatan skor rata-rata aktivitas peserta didik yang dapat divisualisasikan pada Gambar 2.

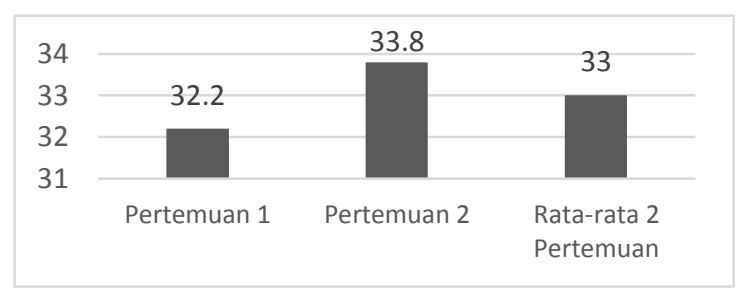

Gambar 2. Peningkatan Aktivitas Peserta Didik
Hasil rekap menunjukkan adanya peningkatan skor rata-rata aktivitas peserta didik yaitu pada pertemuan pertama didapat skor 32,2 dengan kategori sangat tinggi, dan pada pertemuan kedua meningkat menjadi 33,8 dengan kategori sangat tinggi, yang artinya terjadi peningkatan sebesar 1,6 poin dibanding skor pada pertemuan pertama. Rata-rata dua pertemuan menunjukkan skor 33 yang termasuk pada kategori sangat tinggi, sehingga dapat diketahui bahwa perangkat pembelajaran dengan model problem based learning (PBL) bervisi SETS berbantuan Miracast, efektif untuk meningkatkan aktivitas peserta didik. Setelah diidentifikasi peningkatan terjadi karena pada pertemuan kesatu merupakan pertama kalinya peserta didik mengalami kegiatan pembelajaran melalui model problem based learning (PBL) bervisi SETS berbantuan Miracast sehingga masih ada beberapa peserta didik yang kurang aktif dalam mengajukan pertanyaan, memberikan tanggapan, serta ragu-ragu dan merasa takut salah untuk menyampaikan hasil diskusi tentang pemecahan masalah di depan kelas, ada beberapa peserta didik juga masih bingung dalam menganalisis kartu kasus dan mengisi LKPD. pada pertemuan kedua aktivitas peserta didik mengalami peningkatan karena peserta didik mulai memahami pola model problem based learning (PBL) bervisi SETS berbantuan Miracast, mereka lebih berani mengajukan pertanyaan, menanggapi, dan menyampaikan pendapatnya tentang solusi pemecahan masalah karena mereka mengetahui bahwa pendapatnya dihargai oleh guru, semua pendapat peserta didik ditampung oleh guru yang pada akhirnya dianalisis dan dikonfirmasi oleh guru untuk menyamakan persepsi dan konsep setelah kegiatan mengembangkan dan menyajikan hasil karya dilakukan dan kelompok yang paling aktif diberikan penghargaan oleh guru sehingga mereka lebih terntantang untuk aktif dalam pembelajaran. Hasil tersebut menunjukkan bahwa perangkat pembelajaran model problem based learning (PBL) bervisi SETS berbantuan Miracast efektif untuk meningkatkan aktivitas peserta didik. Hasil ini sejalan dengan hasil penelitian yang dilakukan oleh Tillman (2013), siswa dalam pembelajaran PBL didapati secara signifikan memilik tingkat keterlibatan kolaborasi yang tinggi, yang berarti mereka bekerja bersama dalam kelompok dan membantu teman-temannya belajar lebih tinggi jika dibandingkan dengan siswa yang belajar di kelas tradisional, dimana pembelajaran berfokus pada guru dan lembar kerja. Woods (2000) juga menyimpulkan bahwa pembelajaran PBL sangat menunjang kecakapan memecahkan masalah, kerjasama kelompok, dan berkomunikasi.

\section{Kepraktisan Perangkat Pembelajaran}

Kepraktisan perangkat pembelajaran ditentukan berdasarkan hasil respons guru dan respons peserta didik terhadap perangkat pembelajaran yang dikembangkan. Respons empat orang guru terhadap perangkat pembelajaran dengan model problem based learning (PBL) bervisi SETS berbantuan Miracast sangat positif yaitu Guru A memberikan skor 73 dengan kategori 
sangat positif, Guru B memberikan skor 77 dengan kategori sangat positif, Guru C memberikan skor 75 dengan kategori sangat positif, dan Guru D memberikan skor 77 dengan kategori sangat positif. Rata-rata skor respons keempat orang guru tersebut adalah 75,5 yang termasuk dalam kategori sangat positif sehingga dapat diketahui hasil tersebut sudah memenuhi kriteria keberhasilan penelitian untuk respons guru yaitu $\mathrm{Sa}$ menunjukkan kategori $\geq$ positif (minimal 3 guru merespons positif). Guru-guru merespons sangat positif bahwa perangkat pembelajaran sudah sesuai standar proses, pembelajaran melalui model problem based learning (PBL) bervisi SETS berbantuan Miracast sangat bermanfaat karena memfasilitasi guru berkomunikasi secara efektif dengan peserta didik, dapat meningkatkan aktivitas peserta didik, dan mempermudah guru dalam menanamkan konsep atau materi. Guru-guru mendapatkan literasi tekonologi baru terkait pemanfaatan Miracast dalam pembelajaran. Mereka dapat memaksimalkan android atau smartphone yang mereka miliki dalam pembelajaran di kelas sehingga peserta didik bisa lebih termotivasi untuk belajar. Berdasarkan hasil tersebut, perangkat pembelajaran dengan model problem based learning (PBL) bervisi SETS berbantuan Miracast direspons sangat positif oleh guru di SD.

Sementara itu, Hasil respons peserta didik diperoleh dari pengisian lembar angket respons peserta didik terhadap perangkat pembelajaran dengan model problem based learning (PBL) bervisi SETS berbantuan Miracast, yang terdiri dari lima indikator yaitu: 1) kesukaan peserta didik terhadap pembelajaran tematik, 2) kebermaknaan penerapan model problem based learning (PBL) bervisi SETS berbantuan Miracast, 3) penggunaan media, 4) keterbacaan LKPD, dan 5) Keterbacaan PPHB. Kelima indikator tersebut selanjutnya dijabarkan dalam 20 pernyataan. Hasil rekapitulasi menunjukkan 26 dari 30 peserta didik merespons sangat positif terhadap perangkat pembelajaran dengan model problem based learning (PBL) bervisi SETS berbantuan Miracast yaitu dengan jumlah skor respons antara 66 sampai 80. Jumlah peserta didik yang merespons postif perangkat pembelajaran adalah 4 orang dengan jumlah skor respons antara 51 sampai 65 sehingga tidak ada peserta didik yang merespons negatif. Peserta didik sangat senang dan baru mengetahui bahwa smartphone juga bisa digunakan dalam pembelajaran melalui pemanfaatan Miracast. Hal tersebut menunjukkan sudah terpenuhinya kriteria keberhasilan untuk respons peserta didik yaitu Sa (minimal 20 dari 26 peserta didik di kelas ujicoba real teaching) menunjukkan kategori $\geq$ positif. Rata-rata skor respons seluruh peserta didik adalah 72,3 yang termasuk kategori sangat positif sehingga dapat diketahui bahwa perangkat pembelajaran dengan model problem based learning (PBL) bervisi SETS berbantuan Miracast direspons sangat positif oleh peserta didik di kelas uji coba real teaching.

\section{PENUTUP \\ Simpulan}

Karakteristik perangkat pembelajaran perangkat pembelajaran dengan model problem based learning (PBL) bervisi SETS berbantuan Miracast adalah dikembangkan sesuai dengan Standar Proses, menerapkan pembelajaran tematik terpadu, menerapkan pendekatan scientific, dan dikembangkan dengan model problem based learning (PBL) bervisi SETS berbantuan Miracast. Perangkat pembelajaran dikembangkan untuk kelas IV SD dengan tema "Selalu Berhemat Energi", subtema "Energi Alternatif". perangkat pembelajaran yang dikembangkan meliputi: silabus, rencana pelaksanaan pembelajaran (RPP), lembar kerja peserta didik (LKPD), media, dan perangkat penilaian hasi belajar (PPHB).

Kevalidan perangkat pembelajaran ditentukan berdasarkan penilaian dan pendapat 3 orang ahli (judgement expert). Berdasarkan hasil validasi oleh tiga orang ahli terhadap perangkat pembelajaran model problem based learning (PBL) bervisi SETS berbantuan Miracast sudah memenuhi kriteria valid. Perangkat pembelajaran yang dikembangkan efektif untuk meningkatkan hasil belajar kognitif peserta didik yang terlihat dari hasil postes yang menunjukkan 25 dari 30 peserta didik tuntas KKM. Hasil uji N-gain juga menunjukkan nilai gain $\langle g\rangle$ sebesar 0,48 dalam kategori sedang. Rekapitulasi Hasil pengamatan juga menunjukkan adanya peningkatan skor rata-rata aktivitas peserta didik, yaitu pada pertemuan pertama didapat skor 32,2 dengan kategori sangat tinggi, dan pada pertemuan kedua meningkat menjadi 33,8 dengan kategori sangat tinggi. perangkat pembelajaran efektif untuk meningkatkan aktivitas peserta didik. Kepraktisan perangkat pembelajaran terlihat dari hasil skor akhir respons guru 75,5 yang termasuk dalam kategori sangat positif dan hasil rata-rata skor respons seluruh peserta didik 72,3 yang termasuk kategori sangat positif. Berdasarkan hasi tersebut, diketahui bahwa perangkat pembelajaran model problem based learning (PBL) bervisi SETS berbantuan Miracast sudah memenuhi kriteria valid, efektif, dan praktis.

\section{Daftar Pustaka}

Alliance, W. (2012). Wi-Fi CERTIFIED Miracast: Extending the Wi-Fi Experience to Seamless Video Display. USA: Wi-Fi Alliance.

Arends, R. I. (2012). Learning to Teach. New York: McGrow-Hill Companies, Inc.

Asus. (2013). Asus Miracast Dongle in Search of Incredible: E-Manual. ASUSTek Computer Inc.

Barrows, H. S. (1996). Problem-based learning in medicine and beyond: A brief overview [JOUR]. New Directions for Teaching and Learning, 1996(68), 3-12.

Binadja, A. (1996). Why Do We Need SETS Education. 
Paper Submitted for Training and Workshop on Environmental Education, Brisbane. CONF.

Binadja, A. (1999). STL (Science Technology Literacy) in the SETS (Science, Environment, Technology and Society) Perspective. CONF. regional workshop on scientific and technological Ilitercy for all conducted ....

Darmawan, A. (2017). K13 Dievaluasi, Dindik Kota Malang Temukan Kelemahannya - MalangVoice. Retrieved April 27, 2018, from http://malangvoice.com/k13-dievaluasi-dindikkota-malang-temukan-kelemahannya/

Flynn, A. E., \& Klein, J. D. (2001). The influence of discussion groups in a case-based learning environment [JOUR]. Educational Technology Research and Development, 49(3), 71-86.

Fullan, M. (2013). Stratosphere: Integrating technology, pedagogy, and change knowledge [BOOK]. Pearson Canada.

Hmelo-Silver, C. E. (2004). Problem-Based Learning: What and How Do Students Learn? Educational Psychology Review, 16(3), 235-266. https://doi.org/10.1023/B:EDPR.0000034022.1647 $0 . \mathrm{f3}$

Jawapos. (2016). penerapan k-13 Bikin Guru Bingung. Retrieved April 27, 2018, from https://www.jawapos.com/read/2016/07/24/40969/ penerapan-k-13-bikin-guru-bingung

Masfuah, S., Masfuah, S., Rusilowati, A., \& -, S. (2012). PEMBELAJARAN KEBENCANAAN ALAM DENGAN MODEL BERTUKAR PASANGAN BERVISI SETS UNTUK MENUMBUHKAN KEMAMPUAN BERPIKIR KRITIS SISWA. Jurnal Pendidikan Fisika Indonesia, 7(2). https://doi.org/10.15294/jpfi.v7i2.1083

Mergendoller, J. R., Maxwell, N. L., \& Bellisimo, Y. (2006). The effectiveness of problem-based instruction: A comparative study of instructional methods and student characteristics [JOUR]. Interdisciplinary Journal of Problem-Based Learning, 1(2), 5.

Mulyasa, E. (2011). Menjadi Guru Profesional. Bandung: Remaja Rosdakarya.

Permendikbud Nomor 81a Tahun 2013 tentang Implimentasi Kurikulum 2013. Jakarta: Kemendikbud.

Permendikbud Nomor 22 Tahun 2016 tentang Standar Proses. Jakarta: Kemendikbud.

Permendikbud No. 24 tahun 2016 tentang kompetensi inti dan kompetensi dasar pelajaran pada kurikulum 2013. Jakarta: Kemendikbud.

Piaget, J. (2001). The Psychology of Intelligence "Translated by Malcolm Piercy and D.E Berlyne." London \& New York: Routledge Classics.
Rusilowati, A., Rusilowati, A., -, S., Binadja, A., \& Mulyani, S. E. S. (2012). MITIGASI BENCANA ALAM BERBASIS PEMBELAJARAN BERVISI SCIENCE ENVIRONMENT TECHNOLOGY AND SOCIETY. Jurnal Pendidikan Fisika Indonesia, $8(1)$ https://doi.org/10.15294/jpfi.v8i1.1994

Sugiyono. (2013). Metode Penelitian Pendidikan: Pendekatan Kuantitatif, kualitatif, dan $R \& D$. Bandung: Alfabeta.

Thiagarajan, S., Semmel, D. S., \& Semmel, M. I. (1974). Instructional development for training teachers of exceptional children [GEN]. Minneapolis, Minnesota: Leadership Training Institute/Special Education ....

Tillman, D. (2013). Implications of Problem Based Learning (PBL) in elementary schools upon the K12 engineering education pipeline [CONF]. 2013 ASEE Annual Conference \& Exposition, 23-709.

Wade, R. (2002). Beyond Expanding Horizons: New Curriculum Directions for Elementary Social Studies. The Elementary School Journal, 103(2), 115-130. https://doi.org/10.1086/499719

Wijayama, B. (2018). PENINGKATKAN EFEKTIVITAS PEMBELAJARAN IPA BERVISI SETS DENGAN PENDEKATAN SAVI UNTUK PEMBENTUKAN KARAKTER PESERTA DIDIK SEKOLAH DASAR NEGERI SADENG 03 [JOUR]. MAGISTRA: Media Pengembangan Ilmu Pendidikan Dasar Dan Keislaman, 7(1).

Winataputra, U. S. (2008). Teori Belajar dan Pembelajaran. Jakarta: Universitas Terbuka.

Woods, D. R. (2000). Helping your students gain the most from PBL [JOUR]. Problem-Based Learning: Educational Innovation across Disciplines. Singapore: Temasek Centre for Problem-Based Learning. 